Please do not remove this page

RMIT

UNIVERSITY

\title{
Curriculum design of a flipped classroom to enhance haematology learning
}

Porcaro, Pauline; Jackson, Denise; McLaughlin, Patricia; O'Malley, Cindy

https://researchrepository.rmit.edu.au/esploro/outputs/9921862862401341/filesAndLinks?institution=61RMIT_INST\&index=null

Porcaro, P., Jackson, D., McLaughlin, P., \& O'Malley, C. (2016). Curriculum design of a flipped classroom to enhance haematology learning. Journal of Science Education and Technology, 25(3), 345-357.

https://doi.org/10.1007/s10956-015-9599-8

Document Version: Accepted Manuscript

Published Version: https://doi.org/10.1007/s10956-015-9599-8

Repository homepage: https://researchrepository.rmit.edu.au

(c) Springer Science+Business Media New York 2016

Downloaded On 2023/04/26 22:14:34 +1000

Please do not remove this page 
Thank you for downloading this document from the RMIT Research Repository.

The RMIT Research Repository is an open access database showcasing the research outputs of RMIT University researchers.

RMIT Research Repository: http://researchbank.rmit.edu.au/

\section{Citation: \\ Porcaro, P, Jackson, D, McLaughlin, P and O'Malley, C 2016, 'Curriculum design of a flipped classroom to enhance haematology learning', Journal of Science Education and Technology, pp. 1-13.}

See this record in the RMIT Research Repository at:

https://researchbank.rmit.edu.au/view/rmit:35191

Version: Accepted Manuscript

Copyright Statement: @ Springer Science+Business Media New York 2016

Link to Published Version:

http://dx.doi.org/10.1007/s10956-015-9599-8 


\section{Abstract}

A common trend in higher education is the "flipped" classroom, which facilitates active learning during class. The flipped approach to teaching was instituted in a haematology 'major' class and the students' attitudes and preferences for the teaching materials were surveyed. The curriculum design was explicit and involved four major components 1 ) the preparation of the students; 2) the weekly pre-class work; 3) the in-class active learning strategies and 4) closing the learning loop using formative quizzes. Each of these components is discussed in detail and was informed by sound pedagogical strategies. Several different sources of information and several freely available software tools to engage the students are discussed.

Two iterations are reported here, with improved pass rate for the final examination from $47-48 \%$ in the traditional class to $56-65 \%$ in the flipped classroom approach. The majority of students $(93 \%$ and 89\%) came to the class prepared, after viewing the screencasts and engaged fully with the activities within the face-to-face time. The students perceived that solving case studies (93\%) was the most beneficial activity for their learning and this was closely followed by the production of essay plans (71\%). The majority of students recommended that this approach be repeated the following year (69\% and 75\%). (204 words)

Keywords: flipped classroom, active learning, curriculum design.

\section{Introduction}

The concept of the Flipped Classroom is not new, it has been proposed in various forms since 2000 initially as the inverted classroom (Lage Platt and Treglia 2000). It has been popularised and promoted by Bergmann and Sams (Bergmann 2012) and whilst most of the early proponents teach in K12 classes, it has also been introduced into some tertiary programs. Bergmann founded the online resource, the Flipped Learning Network to disseminate information and promote the generation of research into this approach and also provide access to professional development opportunities 
for teachers. In Australia, the University of Adelaide has mandated that lectures are to be phased out for all courses from 2016 (Dodd 2015) and this has invited some comment (Dawson 2015) and vigorous discussion within higher education institutions. There is no single definition of a flipped classroom, nor is there a single way of delivering this type of course, however at the centre is the introduction of active learning in to the classroom (Stone 2012 \& Smith 2014). Active learning has been defined in a myriad of ways (Dufresne 1996; Prince 2004; Andrews 2011) but central to each of these definitions is that it facilitates the student to construct their knowledge about a topic.

This is the latest pedagogical trend - but it can not yet be considered to be evidence-based (Abeysekera 2014). The literature reports are becoming more focussed on structuring studies with in-built controls, but as yet, there are too few of these to be absolutely certain that this pedagogical approach is based on clear and reproducible data and such studies are difficult to interpret without a large number of students. Problems inherent to pedagogical research are that it is difficult to separate out and isolate independent and dependent variables and, indeed to determine the mode of measurement (Berliner 2002). In fact, Berliner suggests that educational research should NOT be measured in isolation as scientific studies because the context, the complex social interactions and also the changes due to the wider social context must be considered and are an ever-changing landscape. One such scientific study, (Jensen 2015) suggested that the benefits of the flipped classroom may indeed be due to the incorporation of active learning within these face-to-face sessions. This is unsurprising to those who ponder the merits and strategies to implement when designing such a course.

\section{Previous Studies on Active Learning}

The evidence for the benefits of active learning is somewhat more empirical and has a longer literature pedigree, from 1984 when Benware and Deci demonstrated that students who learned in order to teach were more motivated then those who learned to pass an examination. There are, however, some differences in the definition of Active Learning that may have confounded the literature reports (Prince, 2004). A summary of the literature on active learning prior to 1991, 
concluded that active learning could improve students' attitudes, thinking and writing (Bonwell, 1991). A later review suggests that different active learning methods should be assessed separately given that there are many different guises of active learning. However, this author also suggests that the "empirical support for active learning is extensive" and breaks this down into different parts activity in lectures, collaborative learning and co-operative learning all of which demonstrate benefits to academic achievement, student attitudes and may also improve student retention (Prince, 2004). Michael (2006) presents evidence that active, student-centred learning is better than passive approaches and that this is not from the results of any particular experimental design, but that the wide range of studies from different disciplines and varying student cohorts builds to a sufficient weight of evidence to satisfactorily conclude this. A recent meta-analysis of 225 studies (Freeman 2014) demonstrated an increase in examination scores and reduced failure rates in active learning courses when compared to traditional lecturing in undergraduate STEM disciplines. However, there are others who demonstrate that active learning may be incorporated with no benefit when discipline experts who are not also expert teachers implement these strategies (Andrews 2011). Thus, the implementation of active learning strategies must be informed by educational research and good practice and it may be that educational experts should be included in the teaching teams to facilitate and mentor good practice. Discipline experts may not be able to properly incorporate and deliver these strategies without such assistance.

The recent upsurge in interest in active learning and the flipped classroom has been facilitated by the increase in the number and accessibility of technologies to enable their implementation. Free software are available for fun, gamified quizzing (eg Kahoot! and Quizizz) and also for more measured and more flexible feedback-rich quizzing (Socrative). Regular quizzing in class has been demonstrated to improve the student outcome in examinations (Marcell, 2008; Roediger, 2011; Sun, 2013). Various websites offer word cloud assembly and, increasingly have analytics associated. These have been used extensively for reflection and discussion in both face-to-face and on-line courses and to encourage proactive learning (Hamm, 2011; Miley,2011; Paily,2013). Mind/concept 
mapping tools are also available which assist the students to make links between various topics and concepts. The empirical data to demonstrate the efficacy of mind and concept mapping is lacking, however, a meta-analysis that compared 52 studies does begin to suggest that there is some positive impact on teaching and learning (Liu, 2014). However, as learning is the ability to link various themes and topics and utilise them in different novel contexts, this does intrinsically appear to be a useful tool. The limiting factor to the use of these in K-12 teaching is the availability of smart phones/ tablets/computers - however, this is not an issue in higher education institutions in Australia as $89 \%$ of the population own smartphones (Mackay 2014). The personal availability of technology should not, however, be assumed and the power of peer-peer learning can be harnessed in small group work as well. The implementation of active learning strategies is becoming easier and our students are more amenable to digital interactions than ever before and this will only increase with the arrival of Generation $Z$ to universities in the near future (Berkup 2014). These studies create a scaffold for understanding prior research in active learning and informed the design of the haematology class study reported in this paper.

The aims of this study are to evaluate the effect of a change of delivery mode (from the traditional model to the flipped approach) on the students' perceptions and outcomes in a higher education course. This mode of delivery is becoming more common in higher education courses and the design of all activities in such courses must be aligned with the learning outcomes and must be constructed to carefully increase the ability of students to attain the learning outcomes (Benware, 1984; Bonwell, 1991; Armbruster, 2009). The rationale for switching deliver modes is that students who graduate from our program will be engaged in employment using technologies not yet developed and this approach has been shown to foster critical thinking skills and a deeper understanding of the material (Herreld, 2013; Findlay-Thompson, 2014; Kong;2014). This is vital for graduates to be able to adapt to the new technologies and workplaces that they will meet during their careers. 
The framework used for the design of this course and the important steps undertaken are discussed. The efficacy of the active learning undertaken in class was assessed by the students' perceptions of whether the activities undertaken in face-to-face time have improved their learning. This analysis can inform the activities undertaken in similar courses in other institutions. This research paper also provides some information about freely available software that can be used to assist in the delivery of a flipped class. Finally, the impact on the students' marks in the final examination is used as a measure of the success of the flipped delivery approach. These types of instruments have been previously used for the evaluation of the flipped classroom (Toto, 2009; Stone, 2012; Zhang, 2014).

\section{Method}

\section{Rationale:}

The rationale for flipping the haematology 2 class was to increase the ability of students to 'think like a scientist' - to be able to evaluate data (is it good data?) and to interpret that data (what does it mean?). Too often students have rote-learned the material from lectures, but then have been unable to apply the knowledge in the examinations and have then failed that assessment. This lack of analytical skills has presumably also been apparent in their early careers. The laboratory of today is very different to that of 20 years ago and with the technological advances increasing in development it is difficult to imagine the technologies of a laboratory 20 years from now. Graduates from university need to evaluate what is good information and then they need to know how to apply it - the need for them to learn specific information in-depth for each disease is much less now due to the exponential increase in understanding of disease processes and the burgeoning of freely available, open-access journals as sources of reliable information. The flipped classroom approach has been demonstrated to improve engagement (Stone 2012) and analytical skills (Kong 2014) and thus was selected for delivery of the haematology 2 class in 2014 and 2015. 


\section{Course Design Framework:}

The Chinese proverb, "Tell me, I'll forget. Show me, I'll remember. Involve me, l'll understand" was at the forefront of the planning activities. Before undertaking the 'flip' four critical stages in the process were defined:

1. Preparation of the students before semester begins

2. Weekly pre-class work

3. In-class activities

4. Post-class - closing the learning loop.

These are discussed in detail below.

\section{Preparation of the students before semester begins}

The preparation of the students before semester was determined to be one of the most important parts of changing the format of the class. If the students were not engaged from week 1 , then the students may never engage with the new approach and could be left in limbo. The aim of pre-class preparation is to engage the students to come to the first (and every) lectorial class prepared.

Many of the students had never encountered this learning approach before and could be sceptical and expect a passive osmosis of information. In this stage it is important to ensure that the students understand the answers to two questions:

a) Why have you changed the approach to the teaching of this class?

The change to approach is based in pedagogy, but this is not sufficient to engage students in haematology study. The answer to this question lies in the fact that the world is an ever-changing place with significant increases in technology. Diagnostic laboratories where graduates are likely to be employed are changing rapidly also and the students cannot be taught to do tasks on analysers that do not yet exist. Thus, the main objective is to encourage their logical and analytical approach to problem solving, to encourage them to gather, select, evaluate and interpret information and to become life-long learners. Stating this is not enough - they need to construct this conclusion. A 
series of questions in a screencast with images of labs from 20 years ago and current images should be sufficient to demonstrate the point and lead the students to draw this conclusion.

b) What are we going to do?

The students of today are time-poor; they require that their education fits in around the remainder of their lives. Attendance at class and engagement with the active learning within the class is critical to the flipped approach. These two points are not easily compatible and so it is important to build and explain the structure of the active learning within the classes and demonstrate how this will benefit the student in achieving the aims of the course and the program in which they are engaged. As students in higher education are results-focussed, it is useful to emphasise the benefits of the students articulation of concepts during face-to-face time, to build their vocabulary and thus enable better answers during examinations. Scaffolding the learning around Case Studies is an excellent way to link the practices of the profession and emphasise the authenticity of the learning with analytical thinking and interpretation of results. The introduction of spurious results is also an excellent way to improve their evaluation of data and troubleshooting skills. The final important point is to show that this strategy has positively impacted on the examination results of multiple cohorts of students.

The students were prepared by several emails and notices on the learning management system, Blackboard. They were given a link to a fabulous You Tube video by Julie Schell a vocal proponent of this method of learning who explains, 'The Flipped Classroom in 60 seconds'. In 2015, they were shown that students in the previous iteration (2014) had achieved better marks in the examinations with this pedagogical approach. They were also asked to come to class prepared because it would be a new and active class that would better prepare them for their future (unknown) careers.

\section{Weekly pre-class work}

The pre-class work must be engaging. Generation $\mathrm{Z}$ are coming soon to university and they require choice and input into all that they do. Generation $Y$ have been in our classes for some years and have 
been shaped by the digital age and broad access to information and communication (Montana 2008). Providing engaging, preferably digital pre-learning materials is vital - these generations enjoy choice in the selection of material, however, they also require direction so having a range of material is appreciated (Montana, 2008). Ideally, one would provide a "must do" component and an "interesting to do" component. If it is engaging, then many will do all of the pre-learning and if it is linked to something that is already in their sphere of reference, then this is much more powerful. For example, a news report/magazine article/blog of a celebrity with a disease may be used as a hook... then provide a more scholarly report (journal article, reference book, video or screencast) and ask them to compare the information from the two sources. Table 1 contains a short (albeit incomplete) list of websites with free resources that may be suitable for university level courses. There is little of significance for haematology topics.

If there is no information that is suitable, then it is relatively simple to make screencasts using Camtasia, Adobe Captivate or Powerpoint which allow recording of the screen with narration and also will allow quizzes to be embedded within the screencasts. This enables active learning to occur in the pre-class activity and gives immediate feedback to the students on their comprehension of the material before they attend the face-to-face time. Importantly, the screencasts should be less than 15 minutes (Oblinger 2005) to allow easy access to the information. Guo 2013 and 2014, suggests 6 minute videos are optimal for MOOCs.

In the first class the rationale was explained again and the students were asked to complete a survey to determine their anxieties and intent for this new class format. They were also asked to complete another survey at the end of semester (but prior to the examination period) to determine whether their anxieties remained a problem and whether they had accessed the different resources. This study was approved by the RMIT Human Ethics Committee (ASEHAPP 04-14 and BSEHAPP 37-15) and all participants gave informed consent. 
The pre-class learning was a Lectopia recorded lecture in 2014, which was replaced in 2015 by shorter screencasts that covered the material in topic sized chunks and included questioning to engage the student in active learning. Recent improvements to the software, now allow quizzes to be embedded in the screencast and the results sent via email to the lecturer.

\section{In-class activities}

Environments that are motivating for millennial workers, and presumably students, allow collaboration with friends; include humour, fun and irreverence and are respectful of their opinions (Montana 2008). The in-class activities should reflect this. Importantly, the in-class activities should be authentic and engage learners in active learning such that they have to either think about or perform some application of the knowledge that they have acquired prior to face-to-face time.

Free quizzing software is available (Table 2) - some require the academic to register and the students to connect to a browser. Others require both student and academic to join and a third set require the academic to join and the students to download an app for their device. Regardless of the technology selected (see Table 2), the use of quizzing software is an engaging tool to ensure that students have understood the pre-learning and can be used as fast formative feedback. The results may inform the topics to be discussed within the face-to-face time, to ensure that students do gain understanding before moving on to the next topic. By including some reasoning questions in the quizzes, the student's ability to apply the knowledge may also be tested. The answers to the quizzes may be given to the student directly to their devices (Socrative), or may be followed after each specific question by a whole class review - where an explanation from one of the students who selected the correct answer could enlighten the class with their thought processes. To enable this to occur, the students must feel that they are supported in the class and that there is a community of learners, all of whom feel comfortable when they make mistakes. The mistakes are great learning tools - often these are the same common errors that crop up in exam answers and so highlighting these can be a very positive tool as long as the student is made to feel that they have positively contributed by their answer. 
There are some fun-laden quizzing software programs freely available on the Internet - of note are Kahoot! and Quizizz. They are slightly different, but each has a component of fun and competition which can be energising in a flipped classroom - or in a didactic lecture to create a short interlude and check for comprehension. Socrative is another type of quizzing software that does not have the funky music, but does deliver the question and feedback directly to the students' devices. It also has a wider range of possible question types and can be run in competition mode (space race). All named software allows the students' answers to be downloaded for later analysis. These quizzes can be formative or summative or they can inform the topics that require further explanation during the lectorial time.

Word clouds are images that can be generated from words and give prominence to the most oft repeated words by increasing the font size. For example, these can be generated in class by asking students to email three words relating to a topic and cutting and pasting these into a website. Once the word cloud is generated, the students can then deconstruct the word cloud in small groups and then share with the remainder of the class. The articulation of the concepts is a powerful learning tool for the students - the truism that you cannot teach what you do not truly understand ensures that students who do stumble in their explanations, but might have felt that they know the work, realise that they might need some more study to attain true understanding. Furthermore, the word clouds are useful revision tools for that topic. One of the major advantages of using Word Clouds in class is that the students feel ownership of the word cloud and they are much more willing to discuss the meaning of these words. Some examples of free software available are shown in Table 3. One improvement that could be made to such software is to enable students to directly enter their words directly in a collaborative manner - this would make the process more seamless.

Mind or concept mapping can also be used in class to help students draw the links between different parts of a topic that may be interrelated. It is important to teach the students how to do this with some simple examples and then lead into more complex examples as their confidence and expertise 
improves. Some students may already be experts at this and use them extensively in their studies and exam revision - if so, then encouraging them to show the class how they generate these is also a powerful learning experience. Wikipedia has a list of concept- and mind-mapping software available from https://en.wikipedia.org/wiki/List of concept- and mind-mapping software and there is some preliminary analysis of the features of each.

Authenticity is important - the students need to know WHY they are learning a topic - it should be directly related to their future professional careers and this is easily done by preparing case studies which they can work collaboratively to solve.

Whatever the in class activities entail, there should be a variety of techniques used which will satisfy all learners in the class and should accommodate all learning styles. They should be carefully devised to ensure that students do not simply recall information but learn how to apply the knowledge in novel contexts.

In haematology 2, the students were asked to come to class with three principles/concepts that they could discuss which came from the screencast material. In class, they associated into small groups and discussed these to validate what they thought before opening up the discussion into the wider classroom. Word cloud construction and deconstruction was allocated 20 minutes of the 50 minute session. In other sessions, concept mapping or quizzing replaced the word cloud exercise. Then for any concepts that the students wished reiterating, short 'screencasts' related to the topic were produced after class and this incorporated questioning and active learning processes (Powerpoint presentation with narration recorded using Camtasia). For the final part of the session, collaborative examination of a relevant Case Study or production of an essay plan on the topic (and the same format as that in the final examination) was undertaken.

\section{Post class - closing the learning loop.}

Once the student has acquired the knowledge from the pre-class work and then learned how to apply that knowledge in the face-to-face time, they may also be asked to experiment with this in the 
wet and/or dry practical sessions. This allows for 3-4 contacts with the learning material in a period of time. This reinforcement has been shown to improve the memorisation of facts (Pye 2014). Formative quizzes on the Blackboard site were selected to close the learning loop - the students were allowed to access as many times as they wished. Access was at its peak before the examination period.

\section{Data Collection:}

Students enrolled in Haematology 2 (undergraduate) and Advanced Haematology (postgraduate) courses were surveyed both prior to and after the semester using a questionnaire via Qualtrics. The data collection was approved by the RMIT University Ethics Committee. The student cohort is ethnically diverse - the undergraduate students reflecting the diversity of the population in Melbourne, Victoria. The postgraduate students are also diverse with more than $75 \%$ being international student and the majority have entered postgraduate studies directly after their undergraduate education. Qualitative analysis of the findings from the survey was performed. The final marks from the examinations for the final two years of the traditional approach to teaching were compared to the two years of teaching using the flipped approach by descriptive statistics and graphical representation. Whilst it is widely accepted in the pedagogical literature that comparison of different cohorts in consecutive years with different students is problematic (Berliner, 2002 and Michael, 2013), there is nonetheless sufficient evidence in this study to propose student outcome trends based upon the flipped classroom delivery mode.Cohort characteristicslt is of value in examining this study and the ensuing results to identify the sample cohorts and their demographic characteristics. These data are shown in Table 4. Of note mongst this data is the consistency of age groupings in both 2014 and 2015, across both undergraduate and postgraduate cohorts. Of additional note is the higher numbers of female students (both undergraduate and postgraduate) who completed the questionnaires. Although slightly higher, this differene is reflective of the national averages of students in this cohort 


\section{Results}

In 2014, 21 students responded to the pre-semester survey and 42 students to the post-semester survey, only 13 responded to both surveys. In 2015, 44 students responded to the pre-semester survey and 28 students to the post-semester survey, only 12 responded to both surveys Table 5 shows the responses to the questions in both the pre-semester survey (intention) and the postsemester responses (actuality) and questions only posited post-semester are shown in Table 6.In both iterations, the majority of students $(\geq 90 \%)$ felt that the concept of the flipped classroom had been adequately explained to them. A significant proportion of the students intended to attend all Lectorial sessions (95\% and 95\% in 2014 and 2015, respectively) and to access the material before class ( $86 \%$ and $95 \%)$. However, $73 \%$ and $64 \%$ were anxious about the new method of teaching. This anxiety remained at the end of the semester, but the focus had changed from concern about how the class would go and whether the student would have sufficient time to prepare for class to anxiety about the exams and how well they were prepared. Table 5 demonstrates the pre-semester intention to access the screencasts versus their actual access which was self-declared post-semester. $86 \%$ and $93 \%$ of the students intended to access the screencasts and yet only $64 \%$ and $89 \%$ actually did. In Table 5 the student intent to access the screencasts for revision is shown $-82 \%$ intended to do this at the beginning of semester in 2014 , whereas $100 \%$ intended to do so when questioned at the end of semester but before examination. Furthermore, when they were asked if the screencasts enhanced their learning $95 \%$ answered in the affirmative. The major difference between the responses for the two iterations was that the students in 2015 felt they had learned more haematology during the semester (79\% compared to $38 \%$ in 2014). In both semesters, the majority of students were willing to recommend this format for the following semester (69\% and $75 \%)$. In 2014 , the students intended to access the post-class quizzes (76\%) to close the learning loop, but did not do this (only $12 \%$ ). In 2015 , to try to engage the students with the quizzes, some were performed in class and this appears to have increased the access to the quizzes during semester (43\%), but there remains room for further improvement. 
Only $62 \%$ and $68 \%$ of students attended every lectorial, however, $81 \%$ and $93 \%$ missed fewer than 3 (of 12) sessions (data not shown). The attendance at lectorial was significantly improved over previous iterations of the course, however, this in part was due to a change in the lecture time from 0830 in the morning to 1100 am. Interestingly, the number of students who did access the on-line lecture before class increased marginally from $86 \%$ before semester to 93\% post-semester in 2014 but this trend was reversed in 2015 - 95\% pre- and $89 \%$ post-semester and so may reflect the different students who responded to the survey. In 2014, the question regarding anxiety demonstrated a reduction in number of students with anxiety after semester (52\%) compared to before semester (73\%). Figure 1 compares the self-assessed level of anxiety before and after semester. The anxiety level is clearly reduced post-semester compared to pre-semester. Descriptive statistics show that the mean and standard deviation were $2.59 \pm 1.44$ pre- and $1.39 \pm 1.18$ postsemester.

The screencasts were judged to enhance the students' learning by an overwhelming majority (95\%) of students. In 2014, these were provided as an adjunct to the Lectopia recordings of lectures from the previous traditionally taught class. In 2015, active learning screencasts were prepared for the pre-class activities and there was more variety used in the in-class activities. This is reflected in the students reporting in 2015 that 75\% felt they had learned more haematology during the semester and so they would require less preparation for the final examination, whereas in 2014 only $38 \%$ reported this. Importantly, both cohorts of students would recommend this approach for the next year's class (69\% and 75\%).

When questioned about the areas of their concerns, before semester the students were most worried about having sufficient time to prepare for class, uncertainty about what the class would bring, anxiety re participation in the class and also were worried about missing important information. Post semester these same issues arose as having been of concern, but in addition, concerns about the exam material were raised. There was a small but significant cohort of students 
who wrote that they had a preference for lectures and were not learning as much using this new pedagogical approach. Whether this reflects resistance to change, or whether it is a genuine effect on these students is unknown, but the concerns of this group of students certainly warrant further study.

The students' perceptions of the utility of the active learning exercises performed in class and the positive effect they had on their learning are shown in Table 7. The most impactful active learning exercise (93\% judged it to be very helpful to their learning) was the solution of case studies where they applied the knowledge learned in the pre-class activity, reinforced in the lectorial and then the students solved the case study collaboratively. Also of significant benefit was the generation of essay plans (71\%). Both case studies and essay questions are in the final examination and thus, again, students demonstrate that assessment concerns drive their learning. The articulation of concepts (52\%) and group work (50\%) were also judged to be of significant value - in fact more so than the vehicles that allowed the articulation and group work (concept mapping (33\%), polling (23\%) and word cloud construction and deconstruction (29\%).

The final measure of success of the flipped approach is shown in Figure 2 and Table 8. The total theory component is $50 \%$ of the course and students must pass the theory component to pass the course. The final theory examination is worth $25 \%$ of the final course mark, thus students who fail the exam may pass the course, but those that pass the exam tend to pass the course. Thus, passing the exam is not crucial to success, but is a significant positive predictor of success. In 2012 and 2013, the traditional lecture approach was used and the distribution of marks is bimodal with a peak in the fail range $(<50 \%)$ and also in the pass range $(>50 \%)$. In 2014 and 2015, the distribution of marks is more Gaussian - there is a single peak in the pass range. Furthermore in the flipped approach, there are many fewer students failing badly ( $<40 \%$ marks) and more students achieving good marks $(>70 \%)$. From the distribution curves it appears that the flipped approach assists most those students who would be in the just failed region with traditional teaching approaches, but assists 
them to pass the examination and thus the course. This is also demonstrated in Table 8 where the examination pass rate has increased from $47-48 \%$ with the traditional approach to $56 \%-65 \%$ in the flipped delivery mode. Interestingly, the mean mark for the examination has not significantly improved, however, the median shows a slight improvement in both flipped classes.

\section{Discussion}

The students were prepared for the flipping of the classroom, by notices on Blackboard and also screencasts to prepare them and explain why this approach was being taken. A link to the "Flipped classroom in 60 seconds" video by Julie Schell on YouTube was also provided. In the later iteration, it was also possible to show the improvement in student achievement in the examination from the previous year. The preparation before semester is critical to ensure that the students are prepared before the lectorial and are engaged with the process from the start of semester. For this class, the preparation was well-received and they felt that the concept had been explained to them. This is consistent with previous studies that show that $74 \%$ of students were positive about the flipped approach in an algebra course (Love, 2014) and 75\% of students after studying actuarial techniques with this mode of delivery (Butt, 2014). However, the experience of a nursing cohort demonstrated significantly negative feelings of "frustration, disconnect, depersonalisation and additional time requirements" (Post, 2015). The disparity here may be due to differences in student cohorts or may reflect the preparation of the students prior to the flipped approach being instituted, but this cannot be determined from the literature reports.

In 2015 , the pre-class screencasts were prepared for the class and involved some questioning and active learning that was incorporated into the material to make it more engaging. The length of the screencasts on a topic was variable from 3-20 minutes, but the majority were less than 15 minutes. The optimal length for videos to engage students has not been well studied in the pedagogical literature, but there are various claims. Apparently, Khan (2012) noted that 10 - 15 minutes was the optimal attention span (as reported in Glance 2013). Another internet source claims that the optimal 
length of videos is less than 6 minutes for MOOCs (Guo 2013) and this was further described by the same author in a more academic treatise in 2014. This latter publication also provided several recommendations to improve pre-class videos to engage students. It has also been reported that the attention span of students in a didactic lecture is no more than 10 minutes (Medina 2008) which is the same order as the reported video concentration span. However, whilst one can theorise that there is an 'optimal length' for a video, this may vary markedly based on the delivery, the context and the content of such a video as well as the totally uncontrollable variable of the environment in which it is being watched.

In both iterations of haematology 2 reported here, the students intended to access the learning material $(89 \%, 95 \%)$ before all classes, and this did occur for $93 \%$ and $89 \%$ of respondents. Attendance at lectorial sessions was increased over previous (traditionally taught) lectures, but this was probably in part to a change in scheduling to allow a later time for this activity. However, attendance at the lectorial did drop over both semesters - the intention pre-semester was $95 \%$ and $95 \%$ compared to the actuality of $62 \%$ and $68 \%$. This may reflect the cohort of students who did not enjoy this method of teaching and preferred a more didactic style, or may reflect the increase in workload as the semester passes. The group of students who were resistant to this change in teaching approach may be simply resistant to change or they may have valid reasons that must be considered - this should be examined in greater detail to determine the root cause of this attitude. Most studies have shown that there is a group of students who do not value this approach and further research into understanding their concerns should be undertaken which may then inform better practices to engage these students (Love,2014; Butt, 2014, Post, 2015).

The students of today (Generation Y) and even more the students of tomorrow (Generation Z) are digital immigrants and natives, respectively - they are comfortable with technology, but technology alone is not a motivating factor (Cechova 2013). The students in haematology 2 found the pre-class screencasts enhanced their learning which is consistent with previous studies (Love, 2014; Butt, 
2014). The in-class activities (Table 7) were ranked by the students and the preferred activity to enhance their learning was discussion of case studies. This is authentic learning - this is what medical laboratory scientists do in the diagnostic haematology laboratories. Authentic learning encourages expert thinking and the development of a professional vocabulary and these skills may be the difference between a significant and advancing career and drudgery (Levy,2005). Significantly, these are the skills that we endeavour to lead our students towards. The least preferred active learning strategy was the construction and deconstruction of Word Clouds - however, this was a good way to revisit the material and ensure that all students had understood the material before class. In 2015 , this was further checked by initiating a quiz in the first 5 minutes of the lectorial, composed of 5 multi-choice or short answer questions. This was worth very little in terms of marks (5\% over the 12 lectorials in the semester), however in class discussions, the students strongly requested that it remain and suggested that it should be repeated in the following year. They felt this was both necessary and sufficient to encourage them to actually do the work prior to the lectorial.

The post class activity of quizzing was not a success during semester in the first iteration, but was utilised more when the quizzing was also included in the class activities. However, there is more improvement to be made in this area and will be addressed next year by better preparation with clear emphasis placed on the post-class activities. The quizzes were useful for the majority of students who intended to access them before the final examination. The change to a flipped classroom approach is a huge amount of work for the academic and this was only completed for the second iteration of the class, but the effects of better preparation appear to have been reflected in the improvement in student perceptions of the amount they had learned during the semester - $38 \%$ in 2014 compared to $79 \%$ in 2015 believed they had learned more during semester and thus perceived that they would need less time revising for the examination. Importantly, $69 \%$ and $75 \%$ believed that this approach should be taken for future classes. 
Overall, the flipped haematology 2 classroom was deemed a success because attendance at lectorials was higher than previous lectures and the students' achievement in the final examination was significantly improved. Figure 2 shows that in the traditionally taught classes, there was a bimodal distribution of student marks with peaks in both the fail region and the pass region. In addition, more than 50\% of students failed the examination. In 2014 and 2015, the delivery was flipped and the distribution of results is unimodal - those students who were failing in the traditional classes, were now passing the final examination. The number of students who failed the final examination in 2014 was reduced to $44 \%$ and this reduced even further in 2015 (36\%). This probably represents a better understanding and delivery of the flipped classroom in the later iteration. With further improvements in delivery and engagement, perhaps this can be reduced further. This fits with the large meta-analysis by Freeman (2014) of 225 studies reporting exam scores and/or failure rates in STEM courses that compared traditional lecture delivery to active learning. Their results demonstrate that students in in traditional classes had lower examination scores (6\%) when compared to those in active learning and also were 1.5 times more likely to fail. This effect was more apparent in concept inventory tests than in course examinations and also was apparent in all class sizes, but was most effective in classes with fewer than 50 students.

The aims of this study were to evaluate the effect of a change of delivery mode (from the traditional model to the flipped approach) on the students' perceptions and outcomes in a higher education course. The positive changes in student perceptions and outcomes due to the change in delivery model is evident in this study. The flipped classroom is a much more dynamic and enjoyable space in which to learn and teach - Bergmann states that the academic gives up control of the classroom, but this is a rather simplistic explanation and his suggestion that he "no longer teaches science, but teaches students how to learn" is much more relevant. The role of student and teacher is very different in the flipped classroom - the students can and do ask questions and request further information, but the lecturer may still move the discussion into more appropriate areas if students diverge on tangents. An oft quoted truism, "the teacher's role should be as a guide on the side, 
rather than a sage on the stage" was apparently first reported in 1972 by Holter in a quote from Roger Taylor, a doctoral student at Southern Illinois University (as reported in Popik, 2013). This has been appropriated by the flipped learning community as "the guide on the side" relates to the academic's role in the flipped classroom as against "the sage on the stage" in the traditional format.

There are limitations with all pedagogical research and case reports such as these are little more than anecdotal. The requirement for cross-institution, cross-discipline studies with many students is vital to determine the efficacy of the change to a flipped approach. Unfortunately, these are difficult to organise and to ensure similar learning experiences for different cohorts of students with different academics delivering different courses. It has been demonstrated that the flipped approach is not effective when discipline experts who are not also expert teachers deliver the content (Andrews 2011). The University of Adelaide experience in 2016, may thus lead to similar findings. Flipping the classroom should be undertaken thoughtfully, with care and involves a huge amount of preparation. If higher education institutions require academics to change their approach to teaching there needs to sufficient infrastructure (educational and technical developers) and time allotted to the academics to allow them to change their materials to better suit a flipped approach. The free technologies are available, but the plethora of different tools can be overwhelming and determining which tool best fits the purpose can be time-consuming. The higher education institutions should allocate some resources to searching for suitable software and have educational developers to show academics how to best use these tools within their context. Whilst the flipped classroom has many guises, for it to be truly effective it should be delivered by expert teachers and must involve active learning within the face-to-face time.

In spite of the obvious limitations of cohort size and institutional limits, our findings show that attendance at class and the student marks improved but there was a group of students who resisted the flipped approach - all of which were all similar to the findings of Stone 2012. This has also been shown by others, including a large meta-analysis of the literature (Freeman 2014). It is vital that the 
flipped approach and active learning is informed by best practice, sound pedagogical practices and is implemented with intent. Educational developers should be involved in this process to guide and assist the discipline expert in their role. (5900 words for intro onwards).

As with all research into teaching and learning, a variety of factors influence the final outcomes. Both the quantitative and qualitative learning and teaching data captured here is a snapshot in time of a cohort that is constantly changing, growing and maturing in their learning. Longitudinally these differences are multiplied and become more complex when measured against other cohorts undertaking the same studies. So, as with all research, there are limitations to these results. However, these limitations do not diminish the improved learning and student engagement detailed in this paper. Pedagogy and educational research can benefit from the discussion these results provide and contribute to the body of knowledge around active learning and "flipped" delivery modes.

Ethical approval: All procedures performed in studies involving human participants were in accordance with the ethical standards of the RMIT University Ethics committee and with the 1964 Helsinki declaration and its later amendments or comparable ethical standards.

\section{References}

1. Abeysekera, L., \& Dawson P. (2015). Motivation and cognitive load in the flipped classroom: definition, rationale and a call for research. Higher Education Research and Development 34(1),1-14.

2. Andrews, T.M,, Leonard, M.J., Colgrove, C.A., \& Kalinowski S.T. (2011). Active learning not associated with student learning in a random sample of college biology courses. CBE Life Sciences Education 10, 394-405.

3. Armbruster, P., Patel, M., Johnson, E. and Weiss, M. (2009) Active learning and studentcentred pedagogy improve student attitudes and performance in introductory biology. CBELife Sciences Education, 8(3):203-213. 
4. Benware, C.A. and Deci, E.L. (1984) Quality of learning with an active versus passive motivational set. American Educational Research Journal 21(4), 755-765.

5. Bergmann, J.J., Sams, A. (2012). Before you flip, consider this. Phi Delta Kappa 94(2), 25

6. Berkup, S.B. (2014). Working with Generations $X$ and $Y$ in Generation $Z$ period: management of different generations in business life. Mediterranean Journal of Social Sciences 5(19), 218229.

7. Berliner, D.C. (2002). Educational research: the hardest science of them all. Educational Researcher 31(8),18-20.

8. Bonwell, C.C. and Eison, J.A. (1991) Active learning creating excitement in the classroom. ASHE-ERIC Higher Education Report No. 1, George Washington University, Washington DC.

9. Butt, A. (2014) Student views on the use of a flipped classroom approach: evidence from Australia. Business Education \& Accreditation, 6(1) 33-43

10. Cechova I. and Rees M. (2013). Blended Learning as a means to enhance students' motivation and to improve self-governed learning. Proceedings of the International Conference on e-learning ECEL: 71-77

11. Dawson, P. (2015). Will the University of Adelaide's lecture phase-out be a flop? Available from: https://theconversation.com/will-the-university-of-adelaides-lecture-phase-out-be-aflop-44074 Accessed 29 $9^{\text {th }}$ August, 2015.

12. Dodd T. (2015). University of Adelaide is phasing out lectures. AFR Weekend. Available from: http://www.afr.com/technology/apps/education/university-of-adelaide-is-phasing-outlectures-20150625-ghxgoz] Accessed 29 ${ }^{\text {th }}$ August, 2015.

13. Dufresne, R.J., Gerace, W.J., Leonard W.J., Mestre, J.P. \& Wenk L. (1996). Classtalk: A classroom communication system for active learning. Journal of Computing in Higher Education. 7(2), 3-47.

14. Findlay-Thompson, S., and Mombourquette P. (2014) Evaluation of a Flipped Classroom in an undergraduate business course. Business Education and Accreditation, 6(1)63-70. 
15. Freeman, S., Eddy, S.L., McDonough, M., Smith, M.K., Okoroafor, N., Jordt. H., \& Wenderoth, M.P. (2014). Active learning increases student performance in science, engineering, and mathematics. Proceedings of the National Academy of Sciences of the United States of America. 111(23), 8410-8415.

16. Glance, D.G., Forsey, M. \& Riley M. (2013). The pedagogical foundation of massive open online courses. First Monday. 18:5. Available from: http://firstmonday.org/ojs/index.php/fm/article/view/4350/3673]. Accessed $8^{\text {th }}$ September, 2015.

17. Guo P.J. MOOC research: Optimal Video Length for Student Engagement (2013). Available from: http://blog.edx.org/optimal-video-length-student-engagement/] Accessed $8^{\text {th }}$ September, 2015.

18. Guo P.J, Kim, J. and Rubin R. (2014). How video production affects student engagement: an empirical study of MOOC videos. Available from: http://pgbovine.net/publications/edXMOOC-video-production-and-engagement LAS-2014.pdf Accessed $8^{\text {th }}$ September, 2015.

19. Hamm, S.E. (2011) Using word clouds for reflection and discussion in an online course. Teaching Theology and Religion, 14(2)156.

20. Herreld, C.F., and Schiller, N.A. (2013) Case studies and the flipped classroom. Journal of College Science Teaching, 42(5):62-66.

21. Holter S. (1972). Informal, open classroom education returns: Rural school practices revived. Southern Illinoisan (Carbondale, IL). 63A, col. 4.

22. Jensen, J.L., Kummer T.A., \& d M. Goday, P.D. (2015). Improvements from a Flipped Classroom may simply be the fruits of active learning. CBE - Life Sciences Education. 14(1), $\operatorname{ar} 5,1-12$.

23. Kong, S.C. (2014). Developing information literacy and critical thinking skills through domain knowledge learning in digital classrooms: An experience of practicing flipped classroom strategy. Computers and Education. 78,160-173. 
24. Lage, M.J., Platt, G.J and Treglia, M. (2000). Inverting the classroom: A gateway to creating an inclusive learning environment. The Journal of Economic Education. 31(1), 30-43

25. Levy, F., and Murnane, R. (2005). The new division of labor: How computers are creating the next job market. Princeton, NJ: Princeton University Press.

26. Liu, Y., Zhao, G., Ma, G., and Bo, Y. (2014) The effect of mind mapping on teaching and learning- a meta-analysis. Standard Journal of Education and Essay, 2(1), 17-31.

27. Love, B., Hodge, A., Grandgenett, N., and Swift, A.W. (2014) Student lerning and perceptions in a flipped linear algebra course. International Journal of Mathematical Education in Science and Technology, 45(3), 317-324.

28. Mackay, M.M. (2014). Australian Mobile Phone Lifestyle Index $10^{\text {th }}$ Edition. Available from: http://www.aimia.com.au/ampli2014]. Accessed on $8^{\text {th }}$ September 2015.

29. Marcel, M. (2008) Effectiveness of regular online quizzing in increasing class participation and preparation. International Journal for the Scholarship of Teaching and Learning, 2(1): 19.

30. Medina, J.J. (2008). Brain Rules. Seattle, WA: Pear Press.

31. Michael, J. (2006). Where's the evidence that active learning works? Advances in Physiology Education, 30(4):159-167.

32. Miley, F., and Read, A. (2011) Using Word Clouds to develop proactive learners. Journal of the Scholarship of Teaching and Learning,11(2):91-110.

33. Montana, P.J. \& Pettit, F. (2008). Motivating Generation $X$ and $Y$ on the job and preparing $Z$. Global Journal of Business Research. 2(2),139-148

34. Oblinger, D.G. \& Oblinger, J.L. (Eds.) (2005). Educating the net generation. Available from: http://www.educause.edu/educatingthenetgen/Accessed 30 $0^{\text {th }}$ August, 2015.

35. Paily, M.U. (2013) Creating constructivist learning environment: Role of "Web 2.0" technology. International Form of Teaching Studies. 9(1),39-49. 
36. Popik, B. (2013). "Sage on the stage or guide on the side" (teaching terms). Available from: http://www.barrypopik.com/index.php/new york city/entry/sage on the stage or guide on the side teaching terms Access date $8^{\text {th }}$ September, 2015.

37. Post, J.L., Deal, B., and Hermanns, M. (2015) Implementation of a flipped classroom:Nursing students' perspectives. Journal of Nursing Education and Practice, 5(6) 25-30.

38. Prince, M. (2004). Does active learning work: A review of the research. Journal of Engineering Education. 93(3):223 -231.

39. Pye, M.A., Balota, D.A., McDermott, K.B., Tully, T, \& Roediger, III H.L. (2014). Between-list lag effects on recall depend on retention interval. Memory and Cognition. 42(6)965-977.

40. Roediger III, H.L., Argawal P.K., McDaniel M.A and McDermott K.B. (2011) Test enhanced learning in the classroom: long-term improvements from quizzing. Journal of Experimental Psychology, 17(4):382-395.

41. Schell, J. What is a flipped classroom in 60s? Available from: https://www.youtube.com/watch?v=r2b7GeuqkPc Accessed 20th February, 2014.

42. Smith, J.S. (2014). Active Learning Strategies in the Physician Assistant Classroom - the critical piece to a successful flipped classroom. The Journal of Physician Assistant Education. $25(2), 46-49$

43. Stone, B.B. (2012). Flip your classroom to increase active learning and student engagement. $28^{\text {th }}$ Annual Conference on Distance Teaching \& Learning. Available from: https://dtlconference.wisc.edu/

44. Sun J.C-H. (2014) Influence of polling technologies on student engagement: an analysis of student motivation, academic performance and brainwave data. Computers and Education, 72(1):80-89.

45. The Flipped Learning Network. Available from: http://flippedlearning.org/Page/1

46. Toto, R., and Nguyen, H. (2009) Flipping the work design in an industrial engineering course. $39^{\text {th }}$ ASEE/IEEE Frontiers in Education Conference Proceedings. T4F-1-4. 
Zhang, Z. (2014) Construction of online course based on FCM concept. International Conference on Information, Electronics and Computer, Accessed $21^{\text {st }}$ December, 2015 on line at: www.atlantispress.com/php/download_paper.php?id=11206. 
Table 1 Free on-line video sources of information for university level learning

Table 2 Free quizzing software using electronic devices

Table 3 Free word cloud generation software

Table 4 Characteristics of the student respondents to the questionniares

Table 5 Pre and Post semester survey results for 2014 AND 2015

Table 6 Post semester survey results

Figure 1 The anxiety level of the students was self-assessed before and after semester on a Likert scale. The descriptive statistics of the responses (mean \pm standard deviation) before semester was $2.67 \pm 1.43$ and post semester was $2.14 \pm 1.18$

Table 7 The student perceptions of the utility of the active learning exercises

Figure 2 Final examination marks for Haematology 2 students in the period 2012- 2013 (traditional delivery) and 2014-2015 (flipped approach)

Table 8 Final examination results for Haematology 2 students in 2012-2013 (traditional delivery) versus 2014-2015 via flipped delivery mode 
Table 1: Free on-line video sources of information for university level learning

\begin{tabular}{|l|l|}
\hline Content & Web address \\
\hline $\begin{array}{l}\text { Information and Communication Technology } \\
\text { skills }\end{array}$ & https://www.udacity.com/courses/all \\
\hline $\begin{array}{l}\text { Wide range of courses from universities around } \\
\text { the world }\end{array}$ & $\underline{\text { https://www.edx.org/course }}$ \\
\hline $\begin{array}{l}\text { Wide range of courses from universities around } \\
\text { the world }\end{array}$ & $\underline{\text { https://www.coursera.org/ }}$ \\
\hline $\begin{array}{l}\text { Videos, 3-D animations, Study Notes and On-line } \\
\text { tests on predominantly science and health topics }\end{array}$ & $\underline{\text { http://www.learnerstv.com/videos.php }}$ \\
\hline $\begin{array}{l}\text { Arguably the broadest selection of videos } \\
\text { arranged into categories for easy searching }\end{array}$ & $\underline{\text { http://videolectures.net/ }}$ \\
\hline $\begin{array}{l}\text { The most famous of all - The Khan Academy has } \\
\text { a broad range of categories and levels of study }\end{array}$ & $\underline{\text { https://www.youtube.com/user/khanacademy }}$ \\
\hline $\begin{array}{l}\text { Wide range of videos on many topics at many } \\
\text { levels }\end{array}$ & $\underline{\text { http://www.allversity.org/ }}$ \\
\hline $\begin{array}{l}\text { 1000+ MOOCs in a broad range of categories } \\
\text { Many good, bad and indifferent videos here - }-\end{array}$ & $\underline{\text { http://freevideolectures.com/free-college- }}$ \\
\hline $\begin{array}{l}\text { courses-online/ } \\
\text { but this can be useful in terms of evaluation of } \\
\text { information }\end{array}$ & \\
\hline
\end{tabular}

Table 2: Free quizzing software using electronic devices

\begin{tabular}{|l|l|l|}
\hline Software & Advantages & Website \\
\hline Kahoot! & $\begin{array}{l}\text { Fun, gamified, easy to } \\
\text { use, analytics available }\end{array}$ & www.getkahoot.com \\
\hline Quizizz & $\begin{array}{l}\text { Fun, gamified, easy to } \\
\text { use, analytics available }\end{array}$ & http://quizizz.com/ \\
\hline Socrative & $\begin{array}{l}\text { Questions in the students } \\
\text { device, written feedback } \\
\text { to student's device. } \\
\text { Analytics available }\end{array}$ & htt/www.socrative.com/ \\
\hline Qualtrics & $\begin{array}{l}\text { More of a survey tool - } \\
\text { non-active and wholly } \\
\text { anonymous }\end{array}$ & http://rmit.asia.qualtrics.com/ControlPanel/ \\
\hline Qzzr & $\begin{array}{l}\text { Quick quiz creation, but } \\
\text { requires distribution of a } \\
\text { URL. Can embed in social } \\
\text { media. Not active learning } \\
\text { environment. }\end{array}$ & http://www.qzzr.com \\
\hline
\end{tabular}


Table 3: Free word cloud generation software

\begin{tabular}{|c|c|c|}
\hline Software & Advantages & Website \\
\hline Wordle & $\begin{array}{l}\text { Simple to use, re-do very simple, Can enter URL } \\
\text { instead of pasting words. }\end{array}$ & $\begin{array}{l}\text { http://www.wordle.net/creat } \\
\text { e }\end{array}$ \\
\hline Worditout & $\begin{array}{l}\text { Can filter out words, change the font, colours and } \\
\text { retain the original words and analysis. Can enter URL } \\
\text { instead of pasting words. }\end{array}$ & $\begin{array}{l}\text { http://worditout.com/word- } \\
\text { cloud/make-a-new-one }\end{array}$ \\
\hline $\begin{array}{l}\text { Word } \\
\text { Cloud }\end{array}$ & $\begin{array}{l}\text { Can change the appearance easily and watch the } \\
\text { effect of the changes }\end{array}$ & $\begin{array}{l}\text { https://www.jasondavies.com } \\
\text { /wordcloud }\end{array}$ \\
\hline Tagxedo & $\begin{array}{l}\text { Can paste words, use URL or blog, twitter feed, can } \\
\text { produce in numerous shapes. }\end{array}$ & http://www.tagxedo.com/ \\
\hline $\mathrm{ABCYa}$ & $\begin{array}{l}\text { Word clouds for kids - can filter words, adjust the } \\
\text { word count, change colour, layout and font }\end{array}$ & $\begin{array}{l}\text { http://www.abcya.com/word } \\
\text { clouds.htm }\end{array}$ \\
\hline Tagcrowd & $\begin{array}{l}\text { Can determine the maximum number of words to } \\
\text { show, can group similar words, converts to lowercase } \\
\text { and various words can be excluded }\end{array}$ & http://tagcrowd.com/ \\
\hline $\begin{array}{l}\text { Image } \\
\text { Chef }\end{array}$ & $\begin{array}{l}\text { A site with many other uses, the word cloud can take } \\
\text { various shapes, colour and font are variable. }\end{array}$ & $\begin{array}{l}\text { http://www.imagechef.com/ic } \\
\text { Lword mosaic/ }\end{array}$ \\
\hline
\end{tabular}

Table 4: Characteristics of the student respondents to the questionniares

\begin{tabular}{|l|c|c|c|c|c|c|c|}
\hline & & \multicolumn{3}{|c|}{ Undergraduate Students } & \multicolumn{3}{c|}{ Postgraduate Students } \\
\hline & Total & $\begin{array}{l}\text { Age } \\
\text { (years) }\end{array}$ & Male:Female & $\begin{array}{l}\text { Australian- } \\
\text { born }\end{array}$ & $\begin{array}{l}\text { Age } \\
\text { (years) }\end{array}$ & Male:Female & $\begin{array}{l}\text { Australian- } \\
\text { born }\end{array}$ \\
\hline 2014 (pre) & 21 & $21-27$ & $3: 3$ & 4 & $24-40$ & $7: 8$ & 5 \\
\hline 2014 (post) & 42 & $22-36$ & $4: 5$ & 6 & $23-40$ & $11: 22$ & 8 \\
\hline 2014 (both) & 13 & $22-28$ & $2: 2$ & 3 & $24-37$ & $4: 5$ & 4 \\
\hline 2015 (pre) & & $20-42$ & $2: 7$ & 5 & $22-43$ & $\begin{array}{c}15: 18(2 \\
\text { unknown*) }\end{array}$ & 2 \\
\hline 2015 (post) & 28 & $20-42$ & $\begin{array}{c}1: 12(1 \\
\text { unknown*) }\end{array}$ & 3 & $22-45$ & $9: 5$ & 3 \\
\hline 2015 (both) & 12 & $20-42$ & $1: 5$ & 2 & $22-43$ & $3: 3$ & 2 \\
\hline
\end{tabular}


Table 5: Pre and Post semester survey results for 2014 AND 2015

\begin{tabular}{|c|c|c|c|c|c|c|c|c|}
\hline \multirow[b]{2}{*}{ Question pre-semester survey } & \multicolumn{2}{|c|}{$\begin{array}{l}\text { PRE-SEMESTER } \\
\text { ANSWERS } 2014 \\
\text { (21 respondents) }\end{array}$} & \multicolumn{2}{|c|}{$\begin{array}{l}\text { POST-SEMESTER } \\
\text { ANSWERS } 2014 \\
\text { (42 respondents) }\end{array}$} & \multicolumn{2}{|c|}{$\begin{array}{l}\text { PRE-SEMESTER } \\
\text { ANSWERS } 2015 \\
\text { (44 respondents) }\end{array}$} & \multicolumn{2}{|c|}{$\begin{array}{l}\text { POST-SEMESTER } \\
\text { ANSWERS } 2015 \\
\text { (28 respondents) }\end{array}$} \\
\hline & Yes (\%) & No(\%) & Yes (\%) & No(\%) & Yes (\%) & No(\%) & Yes (\%) & No(\%) \\
\hline $\begin{array}{l}\text { Has the concept of the flipped classroom been explained to } \\
\text { you? }\end{array}$ & $19(90 \%)$ & $2(10 \%)$ & & & $43(98 \%)$ & $1(2 \%)$ & & \\
\hline Do you intend to attend all Lectorial sessions? & $20(95 \%)$ & $1(5 \%)$ & $26(62 \%)$ & $16(38 \%)$ & $42(95 \%)$ & $2(5 \%)$ & $19(68 \%)$ & $9(32 \%)$ \\
\hline $\begin{array}{l}\text { Do you intend to do the pre-learning before any classes } \\
\text { (prac, morphology or face-to-face Lectorial sessions)? }\end{array}$ & $18(86 \%)$ & $3(14 \%)$ & $39(93 \%)$ & $3(7 \%)$ & $42(95 \%)$ & $2(5 \%)$ & $25(89 \%)$ & $3(11 \%)$ \\
\hline $\begin{array}{l}\text { Do you have any anxieties/worries about the format of this } \\
\text { course? }\end{array}$ & $16(76 \%)$ & $5(24 \%)$ & $22(52 \%)$ & $20(48 \%)$ & $28(64 \%)$ & $16(36 \%)$ & $17(61 \%)$ & $11(39 \%)$ \\
\hline $\begin{array}{l}\text { Do you intend to access all of the screencasts on a weekly } \\
\text { basis? }\end{array}$ & $18(86 \%)$ & $3(14 \%)$ & $27(64 \%)$ & $15(36 \%)$ & $40(93 \%)$ & $3(7 \%)$ & $25(89 \%)$ & $3(11 \%)$ \\
\hline $\begin{array}{l}\text { Do you intend accessing the screencasts before the exams to } \\
\text { help you revise for Haematology } 2 \text { ? }\end{array}$ & $17(81 \%)$ & $4(19 \%)$ & $42(100 \%)$ & $0(0 \%)$ & $43(98 \%)$ & $1(2 \%)$ & & \\
\hline Do you intend performing the quizzes weekly? & $16(76 \%)$ & $5(24 \%)$ & $5(12 \%)$ & $37(88 \%)$ & $39(89 \%)$ & $5(11 \%)$ & $12(43 \%)$ & $16(57 \%)$ \\
\hline $\begin{array}{l}\text { Do you intend performing the quizzes before the exams to } \\
\text { help you revise for Haematology } 2 \text { ? }\end{array}$ & $19(90 \%)$ & $2(10 \%)$ & $38(90 \%)$ & $4(10 \%)$ & $43(98 \%)$ & $1(2 \%)$ & $27(96 \%)$ & $1(4 \%)$ \\
\hline
\end{tabular}

Table 6: Post semester survey results

\begin{tabular}{|l|l|l|l|l|}
\hline & $\mathbf{2 0 1 4}(\mathbf{4 2}$ respondents) & \multicolumn{2}{l|}{$\mathbf{2 0 1 5}$ (28 respondents) } \\
\hline Question post-semester survey & Yes (\%) & No(\%) & Yes (\%) & No(\%) \\
\hline Did the screencasts enhance your learning? & $40(95 \%)$ & $2(5 \%)$ & & $6(21 \%)$ \\
\hline $\begin{array}{l}\text { Do you feel that you have learned more haematology during the } \\
\text { semester and thus will need less time revising for the exams? }\end{array}$ & $16(38 \%)$ & $26(62 \%)$ & $22 \%)$ & $7(25 \%)$ \\
\hline $\begin{array}{l}\text { Would you recommend this teaching format for next time this } \\
\text { course is taught? }\end{array}$ & $29(69 \%)$ & $13(31 \%)$ & $21(75 \%)$ & \\
\hline
\end{tabular}


Table 7: The student perceptions of the utility of the active learning exercises

\begin{tabular}{|l|r|r|r|r|}
\hline Question & $\begin{array}{l}\text { Not } \\
\text { helpful (1) }\end{array}$ & $\begin{array}{l}\text { Sometimes } \\
\text { helpful (2) }\end{array}$ & $\begin{array}{l}\text { Very } \\
\text { Helpful (3) }\end{array}$ & Mean \\
\hline Case studies & 0 & 7 & 93 & 2.93 \\
\hline Essay Plans & 4 & 25 & 71 & 2.68 \\
\hline $\begin{array}{l}\text { Articulation of concepts (in group } \\
\text { work or to the entire class) }\end{array}$ & 11 & 37 & 52 & 2.41 \\
\hline Group work to discuss concepts & 18 & 32 & 50 & 2.32 \\
\hline Mind mapping/ concept mapping & 22 & 44 & 33 & 2.11 \\
\hline Anonymous polling & 19 & 58 & 23 & 2.04 \\
\hline $\begin{array}{l}\text { Word cloud construction and de- } \\
\text { construction }\end{array}$ & 32 & 39 & 29 & 1.96 \\
\hline
\end{tabular}

Table 8: Final examination results for Haematology 2 students in 2012-2013 (traditional delivery) and 2014-2015 (flipped approach)

\begin{tabular}{|l|c|c|c|c|}
\hline & 2012 & 2013 & 2014 & 2015 \\
\hline PASS & $47 \%$ & $48 \%$ & $56 \%$ & $65 \%$ \\
\hline Fail & $53 \%$ & $52 \%$ & $44 \%$ & $36 \%$ \\
\hline $\mathrm{n}$ & 51 & 44 & 34 & 34 \\
\hline Mean & 50.4 & 45.5 & 52.3 & 52.4 \\
\hline Median & 48.9 & 48. & 52.0 & 52.7 \\
\hline $\mathrm{SD}=$ & 16.5 & 14.3 & 13.7 & 16.0 \\
\hline
\end{tabular}




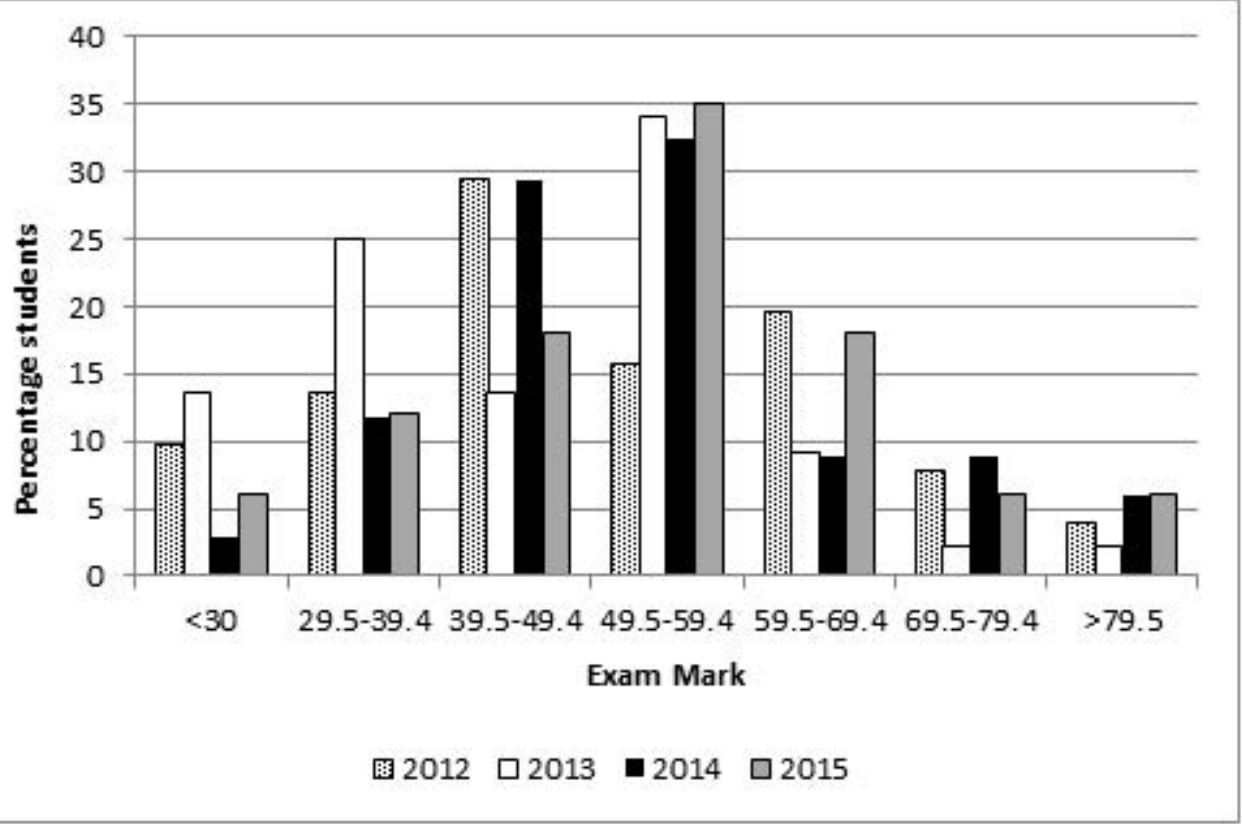

Graph prepared in Excel 